\title{
Pencantuman Hak Opsi Perpanjangan Jangka Waktu Sewa Dalam Perjanjian Sewa Menyewa Rumah (Studi Kasus Putusan Pengadilan Negeri Denpasar Nomor 467/Pdt.G/2014/PN.Dps)
}

\section{Anak Agung Dalem Jagat Krisno ${ }^{1}$ I Nyoman Sirtha ${ }^{2}$ Dewa Gde Rudy ${ }^{3}$}

1Fakultas Hukum Universitas Udayana,E-mail: dalemrockidz@ymail.com

${ }^{2}$ Fakultas Hukum Universitas Udayana

${ }^{3}$ Fakultas Hukum Universitas Udayana

\begin{tabular}{l}
\hline Info Artikel \\
Keywords : \\
Legal Consequences, Option \\
Rights, Lease Agreement \\
Corresponding Author: \\
Anak Agung Dalem Jagat \\
Akibat Hukum, Hak Opsi, \\
Perjanian serwa menyewa
\end{tabular}

\begin{abstract}
Indonesian Civil Code, Act Number 1 of 2011 and Government Regulations Number 14 of 2016 does not regulate firmly on the terms of the option rights. Whereas in practice, a lease agreement that includes an option lease term extension lease clause has generated a dispute between the parties in court. The formulation of the issues to be discussed in this thesis is 1). Is the Denpasar district court decision number 467 / Pdt.G2014 / PN.Dps in relation to the lease term extension option is in compliance with the principles of contract law? 2). What are the legal consequences of the extension of the lease term option in the lease agreement?

The type of research in this thesis is normative legal research because it departs from the void norm in the Indonesian Civil Code, Act Number 1 of 2011 and Government Regulation Number 14 of 2016 is related to the option right to extend the lease term. The types of approaches used are legislation approach, legal concept analysis approach and case approach. Sources of legal materials used are primary legal materials, secondary legal materials and tertiary legal materials. The technique of collecting legal materials is done by document study. The technique of analysis of legal materials used is technique description, evaluation, and argumentation.

The results of research on the issues studied are the court ruling that overrides the tenant's option rights is incompatible with the principle of contract law, the principle of pacta sunt servanda, the principle of good faith and the principle of propierty. The tenant has the option to extend the lease term as stipulated in the lease agreement and the exercise of the right option is done in good faith.
\end{abstract}

\section{Abstrak}

KUHPerdata, UU No. 1 Tahun 2011 dan PP No. 14 Tahun 2016 tidak mengatur seara tegas mengenai ketentuan hak opsi. Sedangkan dalam praktek, perjanjian sewa menyewa rumah yang mencantumkan klausula hak opsi perpanjangan jangka waktu sewa telah menimbulkan sengketa antara para pihak dipengadilan. Adapun rumusan masalah yang akan dibahas dalam tesis ini adalah 


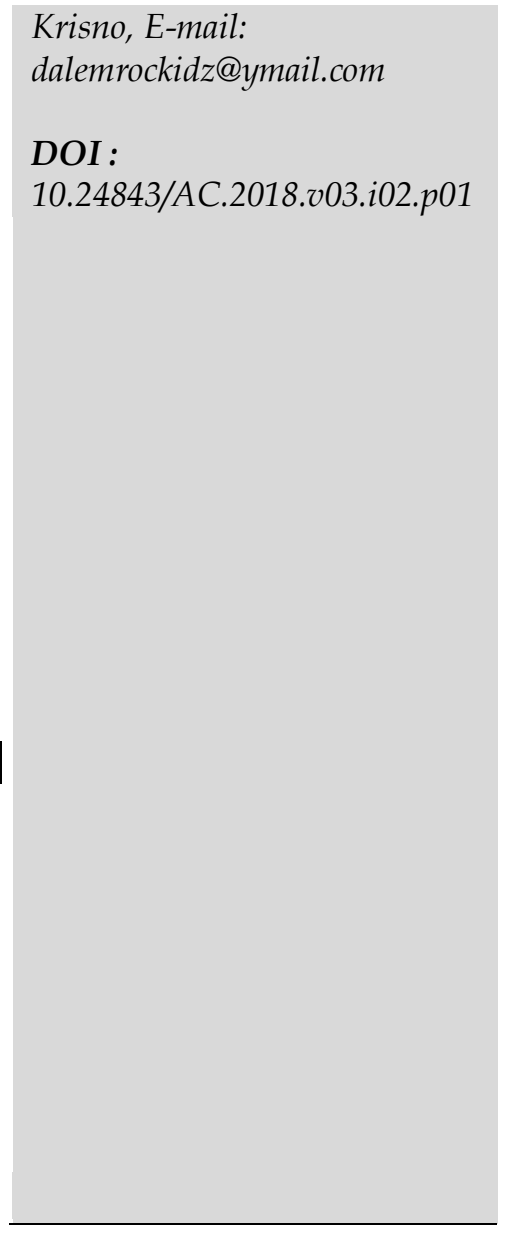

1). Apakah putusan pengadilan negeri Denpasar nomor 467/Pdt.G2014/PN.Dps berkaitan dengan hak opsi perpanjangan jangka waktu sewa sudah sesuai dengan prinsip-prinsip hukum perjanjian? 2). Apa akibat hukum dari penantuman hak opsi perpanjangan jangka waktu sewa dalam perjanjian sewa menyewa rumah? Jenis penelitian dalam tesis ini adalah penelitian hukum normatif karena beranjak dari kekosongan norma dalam KUHPerdata, UU No. 1 Tahun 2011 dan PP No. 14 Tahun 2016 terkait dengan hak opsi untuk perpanjangan jangka waktu sewa. Jenis pendekatan yang digunakan adalah pendekatan perundang-undangan, pendekatan analisa konsep hukum dan pendekatan kasus. Sumber bahan hukum yang digunakan adalah bahan hukum primer, bahan hukum sekunder dan bahan hukum tersier. Teknik pengumpulan bahan hukum dilakukan dengan cara studi dokumen. Teknik analisis bahan hukum yang digunakan adalah teknik deskripsi, evaluasi, dan argumentasi.

Hasil penelitian terhadap permasalahan yang dikaji adalah putusan pengadilan negeri yang mengesampingkan hak opsi yang dimiliki penyewa adalah tidak sesuai dengan prinsip hukum perjanjian yaitu prinsip pactasuntservanda, prinsip itikad baik dan prinsip kepatutan. Pihak penyewa memiliki hak opsi untuk memperpanjang jangka waktu sewa sesuai tertuang dalam perjanjian sewa menyewa rumah dan pelaksanaan hak opsi tersebut dilakukan dengan itikad baik.

\section{Pendahuluan}

Ketentuan mengenai sewa-menyewa rumah diatur dalam Undang-undang Nomor 1 Tahun 2011 tentang Perumahan dan Kawasan Pemukiman (selanjutnya disingkat UU No. 1 Tahun 2011) jo. Peraturan Pemerintah Nomor 14 Tahun 2016 tentang Penyelenggaraan Perumahan dan Kawasan Pemukiman (selanjutnya disingkat PP No. 14 Tahun 2016). Pengaturan penghunian rumah dengan cara sewa-menyewa disebutkan dalam Pasal 50 UU No. 1 Tahun 2011 jo Pasal 28 PP No. 14 Tahun 2016 yang pada intinya mengatur setiap orang berhak untuk bertempat tinggal atau menghuni rumah, dengan status Hak milik sesuai dengan ketentuan perundangundangan; Cara sewa-menyewa, atau Cara bukan sewa-menyewa. Berkaitan dengan rumah yang berstatus sewa awajib dengan perjanjian tertulis.Rumah yang sedang sengketa tidak dapat disewakan. Kebutuhan akan tanah tidak bisa dilepaskan dengan rumah, mengingat rumah menjadi tempat bermukin bagi keluarga, bahkan juga untuk jaminan bank. ${ }^{1}$ Dalam realitanya, rumah bisa diperoleh dengan perjanjian sewa menyewa.

${ }^{1}$ Hasanah, U. (2013). Status kepemilikan tanah hasil konversi hak barat berdasarkan UU no. 5 tahun 1960 tentang peraturan dasar pokok-pokok Agraria dihubungkan dengan PP No. 24 tahun 1997 tentang pendaftaran tanah. Jurnal ilmu hukum, 3(01)., h. 1 
Perjanjian sewa menyewa rumah tunduk pada ketentuan dalam Kitab UndangUndang Hukum Perdata (selanjutnya disingkat KUHPerdata), UU No. 1 Tahun 2011 dan PP No. 14 Tahun 2016. Namun dalam ketentuan tesebut tidak mengatur secara tegas mengenai hak opsi, sehingga dengan tidak adanya pengaturan secara tegas mengenai hak opsi tersebut, maka hal ini dapat menimbulkan permasalahan di kemudian hari.

Permasalahan yang timbul seringkali pada saat pemilik rumah hendak mengakhiri perjanjian. Ketika salah satu pihak merasa dirugikan, maka pihak tersebut berhak menuntut ganti rugi. Salah satu caranya dengan mengajukan gugatan ke pengadilan negeri setempat. Proses penyelesaian sengketa melalui pengadilan bertujuan untuk memulihkan hak seseorang yang telah dirugikan atau terganggu, mengembalikan suasana seperti keadaan semula dan bahwa setiap orang harus mematuhi peraturan hukum perdata, agar peraturan hukum perdata berjalan sebagaimana mestinya. ${ }^{2}$

Kasus dalam penelitian ini adalah perjanjian sewa-menyewa rumah dengan hak opsi perpanjang jangka waktu sewa seperti dalam Putusan Pengadilan Negeri Denpasar Nomor 467/Pdt.G/2014/PN.Dps. Putusan ini akan dianalisa apakah hak opsi untuk perpanjangan jangka waktu sewa rumah dan putusan atas perkara tersebut telah sesuai atau tidak sesuai dengan ketentuan perundang-undangan dan ketentuan perjanjian.

Berdasarkan uraian di atas, maka rumusan masalahnya(1) Apakah Putusan Pengadilan Negeri Nomor 467/Pdt.G/2014/PN.Dps berkaitan dengan hak opsi perpanjangan jangka waktu sewa sudah sesuai dengan prinsip-prinsip hukum perjanjian?; (2) Apa akibat hukum dari pencantuman hak opsi perpanjangan jangka waktu sewa dalam perjanjian sewa-menyewa rumah?

\section{Metode Penelitian}

Jenis penelitian yang digunakan dalam penelitian ini adalah penelitian hukum normatif. Penelitian hukum normatif adalah pemecahan masalah yang didasarkan pada literatur-literatur dan peraturan perundang-undangan yang berkaitan dengan permasalahan yang dibahas, dengan cirinya menggunakan landasan teoritis dan bahan

2Abdulkadir Muhammad, 2000, Hukum Acara Perdata Indonesia, PT. Citra Aditya Bakti, Bandung (selanjutnya disingkat Abdulkadir Muhammad I), hal. 15 
hukum yang terdiri bahan hukum primer dan bahan hukum sekunder. ${ }^{3}$ Penelitian hukum normatif pada penelitian ini beranjak dari kekosongan norma tentang hak opsi dalam ketentuan KUHPerdata, UU No. 1 Tahun 2011 dan PP No. 14 Tahun 2016.

\section{Hasil Dan Pembahasan}

Adapun teori, konsep dan asas yang digunakan dalam penelitian ini, yaitu: Konsep kepastian hukum, teori pacta sunt servanda, asas kebebasan berkontrak, teori ratio decidendi dan teori penemuan hukum.

1. Konsep Kepastian Hukum

Kepastian dalam konsep kepastian hukum memiliki arti ketentuan; ketetapan sedangkan jika kata kepastian digabungkan dengan hukum menjadi kepastian hukum, memiliki arti perangkat hukum suatu negara yang mampu menjamin hak dan kewajiban setiap warga negara. ${ }^{4}$

\section{Teori Pacta Sunt Servanda}

Teori pacta sunt servanda adalah suatu teori yang berasal dan berkembang dalam tradisi hukum Eropa Kontinental. Teori ini mengajarkan bahwa suatu kontrak/perjanjian yang dibuat secara sah dan sesuai hukum yang berlaku, serta sesuai dengan kebiasaan dan kelayakan sehingga diasumsikan sebagai kontrak yang dibuat dengan itikad baik. ${ }^{5}$

3. Asas Kebebasan Berkontrak

Asas kebebasan berkontrak merupakan suatu asas yang memberikan kebebasan kepada para pihak untuk: (1) Membuat atau tidak membuat peranjian; (2) Mengadakan perjanjian dengan siapapun; (3) Menentukan isi perjanjian, pelaksanaan dan persyaratannya; (4) Menentukan bentuknya perjanjian, yaitu tertulis atau lisan. ${ }^{6}$

4. Asas Itikad Baik

Kesepakatan dalam kontrak diwujudkan secara lisan maupun tertulis dengan penandatanganan kontrak oleh para pihak harus dilaksanakan dengan itikad baik. Adapun itikad baik terkandung dalam Pasal 1338 ayat (3) KUHPerdata memuat ketentuan imperatif, yaitu "kontrak harus dilaksanakan dengan itikad baik". Namun, KUHPrdata tidak memberikan penjelasan tentang makna asas itikad baik yang perlu diperhatikan dalam pembuatan dan pelaksanaan kontrak tersebut. Itikad baik adalah

\footnotetext{
${ }^{3}$ Universitas Udayana, 2015, Buku Pedoman Pendidikan Program Studi Magister Kenotariatan Universias Udayana, Denpasar, hal. 54

${ }^{4}$ Anton M. moeliono et. al., 1990, Kamus Besar Bahasa Indonesia, Balai Pustaka, Jakarta hal. 652

${ }^{5}$ Munir Fuady, 2013, Teori-teori Besar (Grand Theory) dalam Hukum, Kencana, Jakarta, hal. 211

${ }^{6}$ Salim, H.S., 2011, Pengantar Hukum Perdata Tertulis (BW), SInar Grafika, Jakarta,hal. 158
} 
istilah yang merupakan terjemahan dari bahasa Belanda, yaitu "te geode trouw" dan dari bahasa Inggris yaitu "in good faith".7

5. AsasKepatutan

Asas kepatutan memberikan arahan pada substansi atau isi kontrak yang disepakati para pihak, yang akan dicantumkan dalam kontrak harus memperhatikan perasaan keadilan (rechtsgevoel) dalam masyarakat. Perasaan keadilan dalam masyarakat inilah yang akan menentukan hubungan hukum yang ada diantara para pihak itu patut atau tidak patut, adil atau tidak adil. ${ }^{8}$

\section{Teori Ratio Decidendi}

Teori ini didasarkan pada pokok perkara yang dipersengketakan, ratiodecidendi artinya inti dari suatu perkara, materialfacts atau faktor sejati yakni bagian yang dapat dianggap mempunyai sifat menentukan dan mengikat pihak yang bersengketa. Sesuai dengan pengertian diatas, ratio decidendi merupakan ketentuan hukum atau proposisi yang diciptakan pengadilan atau dipandang sebagai ketentuan yang harus diperlakukan terhadap perkara yang dihadapi, dan inilah yang disebut sebagai hukum yang diciptakan oleh pengadilan dalam arti sebenarnya. ${ }^{9}$

7. Teori Penemuan Hukum

Penemuan hukum (rechtsvinding) pada dasarnya merupakan wilayah kerja hukum yang sangat luas cakupannya. Penemuan hukum dapat dilakukan oleh orangperorangan (individu), ilmuwan/peneliti hukum para penegak hukum (hakim, jaksa, polisi, dan pengacara/advokat), direktur perusahaan swasta dan BUMN/BUMD. ${ }^{10}$

\subsection{Analisis Putusan Pengadilan Negeri Nomor 467/Pdt.G/2014/Pn.Dps Berkaitan Dengan Hak Opsi Perpanjangan Jangka Waktu Sewa}

Analisis Putusan No: 467/Pdt.G/2014/PN.Dps, berkaitan dengan hak opsi perpanjangan jangka waktu sewa tercantum dalam Pasal 5 perjanjian sewa menyewa Nomor 146 dibuat tanggal 13 juli 1994 serta perubahannya dalam Pasal 6 perjanjian sewa menyewa nomor 267 dibuat tanggal 28 juli 1995, dan yang diganti dengan perjanjian menyewa tempat tercantum dalam article 7.

Hasil dari putusan hakim Pengadilan Negeri Denpasar adalah sebagai berikut :

\footnotetext{
${ }^{7}$ Muhammad Syaifuddin,2012, Hukum Kontrak Memahami Kontrak dalam Perspektif Filsafat, Teori,Dogmatik dan Praktik Hukum (Seri Pengayaan Hukum Perikatan), Mandar Maju, Bandung, hal. 93

8Ibid, hal. 102.

9 Abintaro Prakoso, 2016, Penemuan Hukum: System, Metode, Aliran dan Prosedur dalam Menemukan Hukum, LaksBang PRESSindo, Yogyakarta, hal. 199

10Jazim Hamidi, 2005, Hermeneutika Hukum, UII Press, Yogyakarta, hal. 51
} 
- Menyatakan surat perjanjian sewa menyewa tempat tanggal 1 agustus 2010 dengan obyek rumah yang terletak dijalan mertasari no. 6A, desa intaran kelod, Denpasar selatan, kota Denpasar adalah sah sebagai pengganti akta perubahan perjanjian sewa menyewa no. 267 tanggal 28 juli 1995.

- Menyatakan hukum perbuatan Tergugat I, Tergugat II dan Tergugat III, memaksa hendak memperpanjang sewa rumah milik Penggugat tersebut adalah perbuatan melawan hukum.

| - Menghukum Tergugat I, Tergugat II, dan Tergugat III untuk mengosongkan dan menyerahkan rumah yang terletak di Jalan Mertasari No 6A Desa Intaran, Sanur Kelod, Denpasar Selatan, Kota Denpasar milik Penggugat kepada Penggugat ketika secara lasia bebas dari penguasaan pihak lain, atas dasar putusan yang telah berkekuatan hukum tetap.

Adapun yang mendasari putusan hakim tersebut dilihat dalam pertimbangan hukum halaman 32-34 sebagai berikut:

Menimbang, bahwa dalam Akta Perjanjian No. 146, tanggal 13 Juli 1994 (bukti T.1.2.31) Jo. Akta Perubahan dan Perjanjian Sewa Menyewa No. 267, tanggal 28 Juli 1995 (bukti P-2 = T.1.2.3.-2) Jo. Perjanjian Sewa Menyewa Tempat, tanggal 1 Agustus 2010 (bukti P-3) Jo. Perjanjian Pemindahan dan Penyerahan Hak Sewa, tanggal 18 Nopember 2011, tentang Perjanjian Sewa Menyewa Bidang Tanah (bukti P-4 = T.1.2.33), pada pokoknya diperjanjikan antara lain:

- Perjanjian Sewa Menyewa, Nomor: 146, tanggal 13 Juli 1994 (bukti T.1.2.3-1) dengan isi perjanjian antara lain:

- Pasal 1: "Perjanjian sewa dimulai pada tanggal 1 Agustus 1994 dan diadakan untuk jangka waktu 20 (duapuluh) tahun, sehingga berakhir pada tanggal 1 Agustus 2014. Setelah berakhirnya masa sewa pihak kedua diwajibkan mengembalikan apa yang telah disewa tersebut kepada pihak pertama dalam keadaan kosong....."

- Pasal 4 huruf d: “diperkenankan untuk memindahkan/menyerahkan hak untuk menyewa yang diperoleh kepada pihak lain/orang lain baik untuk sebagian maupun seluruhnya dengan pemberitahuan terlebih dahulu kepada pihak pertama dengan pengertian, bahwa hal tersebut akan didalam batas perjanjian ini";

- Pasal 5:"Pihak pertama memberi hak opsi pertama kepada pihak kedua untuk memperpanjang jangka waktu sewa menurut akta ini untuk 10 (sepuluh) tahun lagi dengan harga sewa yang sama ...."

- Perjanjian Sewa Menyewa, Nomor : 146, tanggal 13 Juli 1994 (bukti T.1.2.3-1) kemudian diubah dengan "Perubahan dan Perjanjian", Nomor :267, Tanggal 28 Juli 1995 (bukti P-2 = T.1.2.3-2), dengan pokok isi perjanjian yang ada pada dasarnya sama dengan apa yang diperjanjikan dalam Perjanjian Sewa Menyewa Nomor : 146 
(bukti T.1.2.3-1), yaitu jangka waktu sewa berakhir tanggal 1 Agustus 2014 (Pasal1) dengan hak opsi pertama kepada pihak kedua (Pasal6) dan hanya dengan perbedaan besarnya harga sewa sebagaimana termuat dalam Pasal 2);

- Perjanjian Sewa Menyewa Tempat, tanggal 1 Agustus 2010 (bukti P-3), antara lain diperjanjikan: masa sewa dapat diperpanjang sampai dengan tanggal 1 Agustus 2024 dengan syarat sebagaimana termuat dalam "Article 2: ..... jikalau pihak kedua tidak dapat membayar uang muka tersebut sebelum 1 Agustus 2012, maka perjanjian berlaku sampai 1 Agustus 2014" dan sesuai Article 7 : perpanjangan jangka waktu sewa harus mendapatkan persetujuan dari pihak pertama;

- Perjanjian Pemindahan dan Penyerahan Hak Sewa" tanggal 18 Nopember 2011 (bukti P-4 = T.1.2.3-3), bahwa tanah dan rumah obyek sengketa oleh Sarita Jill Newson (Pemberi Sewa) telah memindahkan hak penyewaannya kepada Nicole Moia (Warga Negara Prancis) (Tergugat II) dan Adrian Sabine Maxwell Batten ( Warga Negara Inggris) (Tergugat III) sebagai penerima sewa, dengan isi perjanjian, antara lain : jangka waktu sewa berakhir pada tanggal 1 Agustus 2014 dan apabila ingin diperpanjang penerima sewa harus (Pasal 1);

Menimbang, bahwa dalam perjanjian-perjanjian tersebut diatas telah diperjanjikan jangka waktu sewa berakhir sampai dengan tanggal 1 Agustus 2014, dengan pihak pertama memberi hak opsi pertama kepada pihak kedua apabila tanah dan rumah akan disewakan lagi dengan syarat :

- Perbedaan besarnya harga sewa sebagaimana termuat dalam Pasal 2

- Article 2 :...jikalau pihak kedua tidak dapat membayar uang muka tersebut sebelum 1 Agustus 2012, maka perjanjian berlaku sampai 1 Agustus 2014;

- Aritcle 7 : perpanjangan jangka waktu sewa harus mendapat persetujuan dari pihak pertama;

- Setelah berakhirnya masa sewa pihak kedua diwajibkan mengembalikan apa yang telah disewa tersebut kepada pihak pertama dalam keadaan kosong..";

Menimbang, bahwa Penggugat ternyata tidak bermaksud untuk memperpanjang masa sewa, yang kemudian Para Tergugat mensomasi Penggugat agar bersedia memperpanjang masa sewa, sebagaimana surat somasi Para Tergugat yang ditujukan pada Penggugat tertanggal 2 Juni 2014 (bukti P-5) dan tanggal 12 Juni 2014 (bukti P-6);

Menimbang, bahwa perjanjian secara hukum wajib didasarkan adanya suatu kesepakatan oleh para pihak, tanpa adanya kesepakatan tidak mungkin ada perjanjian; 
Menimbang, bahwa perpanjangan sewa dalam perkara aquo didasarkan dengan perjanjian "HAK OPSI" pertama kepada pihak penyewa apabila pemilik tanah dan rumah akan menyewakan hak milik atas tanahnya, tapi secara fakta dalam perkara aquo Penggugat sebagai pemilik tanah dan rumah obyek sengketa tidak bermaksud memperpanjang masa sewa yang dilakukan oleh Para Tergugat, maka sesuai dengan isi perjanjian sewa menyewa antara Penggugat dengan Para Tergugat telah berakhir sejak tanggal 1 Agustus 2014 dan Para Tergugat tidak bisa memaksa pada Penggugat untuk dan harus bersedia memperpanjang masa sewanya sampai dengan tanggal 1 Agustus 2024;

Sedangkan pertimbangan hukum halaman 31 menyebutkan bahwa perjanjian sewa menyewa nomor. 146, "perubahan dan perjanjian", nomor: 267, adalah akta notarial bersifat otentik. Adapun perjanjian tersebut dimuka persidangan tidak dibantah isi kebenarannya oleh para pihak, maka secara hukum merupakan bukti yang sempurna. Sedangkan perjanjian sewa tempat dan perjanjian pemindahan dan penyerahan hak sewa walaupun dibuat dibawah tangan, namun oleh para pihak diakui kebenarannya dalam persidangan, sehingga merupakan bukti yang sah dan sempurna dalam pembuktian pokok perkara.

Sesungguhnya putusan majelis hakim yang menyatakan surat perjanjian sewa menyewa tempat tanggal 1 agustus 2010 sah sebagai pengganti akta perubahan perjanjian sewa menyewa no. 267 sudah tepat. Namun disisi lain putusan majelis hakim telah mengesampingkan hak opsi yang termuat dalam perjanjian sewa menyewa tempat. Adapun hak opsi yang dikesampingkan adalah hak dari pihak penyewa untuk memperpanjang jangka waktu sewa sesuai dengan ketentuan dalam perjanjian sewa menyewa tersebut.

Dengan demikian, putusan majelis hakim yang mengesampingkan hak opsi perpanjangan jangka waktu sewa yang tertuang dalam perjanjian menyewa tempat adalah tidak sesuai dengan prinsip-prinsip perjanjian. Adapun prinsip-prinsip perjanjian yang terdapat dalam Pasal1338 KUHPerdata yakni, prinsip kebebasan berkontrak, prinsip pacta sunt servanda, dan prinsp itikad baik. Bunyi ketentuan Pasal1338 yakni:

Ayat (1) Semua perjanjian yang dibuat secara sah berlaku bagi mereka yang membuatnya. Ayat (2) Suatu perjanjian tidak dapat ditarik kembali selain dengan sepakat kedua belah pihak, atau karena alasan-alasan yang oleh undang-undang 
dinyatakan cukup untuk itu. Ayat (3) Suatu perjanjian harus dilaksanakan dengan itikad baik.

Prinsip kebebasan berkontrak, ditemukan dalam kata "semua" pada Pasal1338 ayat (1) KUHPerdata. Sesuai yang dibahas di bab sebelumnya bahwa pencantuman hak opsi untuk memperpanjang jangka waktu sewa merupakan salah satu bentuk dari penerapan asas kebebasan berkontrak. Untuk prinsip pacta sunt servanda ditemukan pada frasa "berlaku sebagai undang-undang" dalam Pasal 1338 ayat (1) KUHPerdata. Berdasarkan pertimbangan hukum putusan pengadilan negeri Nomor. 467/Pdt.G/2014/PN.Dps pada halaman 31 yang telah disebutkan diatas, dalam pertimbangan hukum intinya mengesahkan perjanjian no. 267 jo. perjanjian menyewa tempat sebagai alat bukti sah dan sempurna adalah tepat. Dengan demikian, perjanjian tersebut mengikat bagi para pihak termasuk juga klausula hak opsi untuk memperpanjang jangka waktu sewa. Sehingga sesuai dengan penjelasan bab sebelumnya juga, maka pihak penyewa memiliki hak opsi untuk memperpanjang jangka waktu sewa dan hak opsi tersebutharus dilaksanakan dengan itikad baik.

Prinsip itikad baik pada Pasal1338 ayat (3) terdapat dalam frasa "suatu perjanjian harus dilaksanakan dengan itikad baik". Dengan demikian, pelaksanaan hak opsi untuk memperpanjang jangka waktu sewa harus dilaksanakan dengan itikad baik. Prinsip itikad baik merupakan kelanjutan dari prinsip pacta sunt servanda, karena suatu perjanjian sebelum dapat dilaksanakan dengan itikad baik maka harus didahulukan dengan keberlakuannya sebagai undang-undang bagi para pihak. Pihak penyewa yang hendak menggunakan hak opsi tersebut sesuai dengan yang tercantum dalam article 7 perjanjian menyewa tempat, maka pemberitahuan keinginan untuk memperpanjang sewa harus diberitahukan terlebih dahulu kepada pihak pemilik paling sedikit dua bulan sebelum akhir masa sewa.

Adapun pemberitahuan tertulis yang dilakukan oleh pihak penyewa berupa somasi. Somasi pertama yang dilakukan oleh pihak penyewa yang isinya memberitahukan keinginan mengunakan hak opsi untuk memperpanjang jangka waktu sewa dan bersedia melakukan pembicaraan secara kekeluargaan untuk mencari solusi yang terbaik, serta diharapakan pihak pemilik dapat memberikan jawaban paling lambat dalam kurun waktu tujuh hari. Namun oleh karena pihak pemilik tidak memberikan tanggapan selama kurun waktu lebih dari tujuh hari, maka pihak penyewa memberikan somasi kedua. Somasi kedua berisikan bahwa penyewa hendak menggunakan hak opsi untuk memperpanjang jangka waktu sewa sesuai dengan perjanjian sewa, dan berdasarkan somasi kedua pihak penyewa hendak menitipkan 
uang (konyiasi) di kepaniteraan pengadilan negeri Denpasar sebagai wujud itikad baik penyewa untuk memperpanjang jangka waktu sewa tersebut.

Bahwa pemilik rumah tidak bermaksud untuk memperpanjang jangka waktu sewa sesuai dengan perjanjian, kemudian pihak penyewa memberikan somasi kepada pemilik rumah yang isinya sesuai yang diterangkan diatas serta perjanjian yang secara hukum wajib didasarkan kesepakatan oleh para pihak, maka dengan alasan tersebut somasi yang dilakukan oleh penyewa sebagai perbuatan melanggar hukum.

Sesungguhnya pertimbangan hukum majelis yang menyatakan pemberitahuan tertulis dalam bentuk somasi oleh pihak penyewa sebagai perbuatan melanggar hukum adalah tidak tepat. Karena somasi tersebut merupakan bentuk pemberitahuan tertulis dari pihak penyewa yang isinya memberitahukan bahwa pihak penyewa hendak menggunakan hak opsi untuk memperpanjang jangka waktu sewa tersebut. Sehingga somasi tersebut merupakan bentuk itikad baik dari penyewa dalam menggunakan haknya sesuai dengan ketentuan perjanjian sewa tempat tersebut.

Jadi, Putusan Pengadilan Negeri Denpasar Nomor 467/Pdt.G/2014/PN.Dps yang berkaitan dengan hak opsi perpanjangan jangka waktu sewa memutuskan mengabulkan gugatan penggugat sebagian adalah tidak sesuai dengan prinsip hukum perjanjian. Klausula hak opsi yang tertuang dalam perjanjian menyewa tempat adalah sah dan mengikat bagi para pihak sesuai dengan prinsip pacta sunt servanda. Penggunaan hak opsi oleh pihak penyewa dalam bentuk somasi merupakan pelaksanaan prinsip itikad baik dari penyewa akibat dari adanya hak opsi dalam perjanjian menyewa tempat tersebut serta telah sesuai dengan asas kepatuan karena pencantuman hak opsi perpanjangan jangka waktu sewa merupakan bentuk perwujudan unsur aksidentalia ke dalam isi perjanjian yang telah disepakati oleh para pihak.

\subsection{Akibat Hukum Dari Pencantuman Hak Opsi Perpanjangan Jangka Waktu Sewa Dalam Perjanjian Sewa Menyewa Rumah}

Perbuatan hukum adalah perbuatan yang akibatnya diatur oleh hukum, baik yang dilakukan oleh satu pihak (bersegi satu) maupun yang dilakukan oleh dua pihak (bersegi dua). Suatu peristiwa yang dikatakan perbuatan hukum apabila terdapat akibat, hal ini dikarenakan akibat dapat dianggap sebagai kehendak dari pembuat (pelaku). Apabila akibatnya tidak dikendaki oleh 
pelaku, maka perbuatan tersebut bukanlah perbuatan hukum. Jadi, adanya kehendak agar dikatakan sebagai perbuatan hukum, perlu diperhatikan unsur esensil yang merupakan perbuatan hukum itu. ${ }^{11}$

Jadi, perjanjian sewa menyewa merupakan perbuatan hukum yang dilakukan oleh para pihak yang menimbulkan akibat hukum.

Akibat hukum dari perjanjian yang dibuat secara sah berdasarkan ketntuan Pasal1338 KUHPerdata yaitu memenuhi syarat-syarat Pasal 1320 KUHPerdata, berlaku sebagai undang-undang bagi mereka yang membuatnya, tidak dapat ditarik kembali tanpa persetujuan kedua belah pihak atau karena alasan-alasan yang cukup menurut undang-undang, dan harus dilaksanakan dengan itikad baik.

a. Berlaku sebagai undang-undang. ${ }^{12}$

Ketentuan ini mengacu pada kekuatan mengikatnya suatu perjanjian. Perjanjian berlaku sebagai undang-undang bagi pihak yang membuat memilik arti bahwa para pihak harus menaati perjanjian itu sama dengan menaati Undang-Undang. Apabila melanggar perjanjian yang mereka buat, maka dianggap sama dengan melanggar undang-undang, yang memiliki akibat hukum tertentu yaitu sanksi hukum. Jadi, barang siapa yang melanggar perjanjian, ia akan mendapat hukuman seperti yang telah ditetapkan pada undang-undang. Perjanjian memiliki kekuatan hukum mengikat dan memaksa.

b. Tidak dapat ditarik kembali secara sepihak ${ }^{13}$

Pada dasarnya perjanjian yang dibuat secara sah tersebut mengikat para pihak, maka perjanjian tersebut tidak boleh ditarik kembali atau dibatalkan secara sepihak. Ketentuan ini mengacu pada perjanjian yang didasarkan pada kesepakatan kedua belah pihak, sehingga pembatalannya harus didasarkan pada persetujuan antara kedua belah pihak. Apabila salah satu pihak ingin membatalkan atau menarik kembali perjanjian tersebut, maka pembatalan atau penarikan perjanjian harulsah mendapat persetujuan dari pihak lainnya. Perjanjian dapat ditarik kembali atau dibatalkan secara sepihak, hanya jika ditemukan alasan-alasan yang cukup menurut UndangUndang.

c. Pelaksanaan dengan itikad baik

Terdapat dua macam itikad baik (in good faith, te goeder trouw) yaitu sebagai unsur subyektif dan sebagai ukuran subyektif untuk menilai pelaksanaan. Dalam hukum benda, istilah itikad baik memiliki arti sebagai kejujuran atau kebersihan. ${ }^{4}$ Pasal531

${ }^{11}$ H. Hilman Hadikusuma, 2005, Bahasa Hukum Indonesia, PT.Alumni, Bandung, hal. 40-41

${ }_{12}$ Abulkadir Muhammad, 1990, Hukum Perikatan, PT. Citra Aditya, Bandung,(selanjutnya disingkat Abdulkadir Muhammad II), hal. 97

${ }^{13}$ Ibid

${ }^{14}$ Ibid, hal. 98 
KUHPerdata memaknai bahwa yang menguasai benda itu beritikad baik, apabila menguasainya dengan cara memperoleh hak milik, tanpa mengetahui cacat yang terkandung di dalamnya. Sedangkan Pasal 533 KUHPerdata menentukan bahwa itikad baik selamanya harus dianggap ada pada setiap orang yang menguasai benda, apabila itikad baik penguasa benda diragukan maka ia harus membuktikan tuduhannya. ${ }^{15}$

Pada dasarnya semua perjanjian yang dibuat secara sah berlaku sebagai undangundang bagi mereka yang membuatnya. Berdasarkan teori Pacta sunt servanda, maka perjanjian sewa menyewa rumah tersebut merupakan perjanjian yang sah dan tidak bertentangan dengan undang-undang sehingga perjanjian tersebut mengikat bagi para pihak dan tidak dapat dibatalkan secara sepihak selain dengan kesepakatan dari kedua belah pihak.

Akibat hukum dari pencantuman hak opsi untuk memperpanjang jangka waktu sewa adalah pihak penyewa memiliki hak pilih pertama untuk memperpanjang jangka waktu sewa sesuai dengan ketentuan perjanjian sewa menyewa rumah, sedangkan pihak yang menyewakan memiliki hak untuk menolak perpanjangan sewa menyewa rumah ataupun menyetujui perpanjangan sewa menyewa rumah dan berhak atas uang sewa. Apabila pihak penyewa hendak menggunakan hak opsi untuk memperpanjang jangka waktu sewa, maka pelaksanaan dari perpanjangan sewa merupakan pelaksanaan isi dari perjanjian yang didasari dengan itikad baik oleh pihak penyewa.

\section{Kesimpulan}

Putusan Pengadilan Negeri Denpasar Nomor 467/Pdt.G/2014/PN.Dps yang berkaitan dengan hak opsi perpanjangan jangka waktu sewa memutuskan mengabulkan gugatan penggugat sebagian adalah tidak sesuai dengan prinsip hukum perjanjian. Klausula hak opsi yang tertuang dalam perjanjian menyewa tempat adalah sah dan mengikat bagi para pihak sesuai dengan prinsip pacta sunt servanda. Penggunaan hak opsi oleh pihak penyewa dalam bentuk somasi merupakan pelaksanaan prinsip itikad baik dari penyewa akibat dari adanya hak opsi dalam perjanjian menyewa tempat tersebut serta telah sesuai dengan asas kepatuan karena pencantuman hak opsi perpanjangan jangka waktu sewa merupakan bentuk perwujudan unsur aksidentalia ke dalam isi perjanjian yang telah disepakati oleh para pihak.

${ }^{15}$ Ibid, hal. 99 
Akibat hukum dari pencantuman hak opsi untuk memperpanjang jangka waktu sewa adalah pihak penyewa memiliki hak pilih pertama untuk memperpanjang jangka waktu sewa sesuai dengan ketentuan perjanjian sewa menyewa rumah, sedangkan pihak yang menyewakan memiliki hak untuk menolak perpanjangan sewa menyewa rumah ataupun menyetujui perpanjangan sewa menyewa rumah dan berhak atas uang sewa. Apabila pihak penyewa hendak menggunakan hak opsi untuk memperpanjang jangka waktu sewa, maka pelaksanaan dari perpanjangan sewa merupakan pelaksanaan isi dari perjanjian yang didasari dengan itikad baik oleh pihak penyewa.

\section{Daftar Pustaka / Daftar Referensi}

\section{$\underline{\text { Buku }}$}

Fuady, Munir, 2013, Teori-teori Besar (Grand Theory) dalam Hukum, Kencana, Jakarta.

Moeliono et. al., Anton M. 1990, Kamus Besar Bahasa Indonesia, Balai Pustaka, Jakarta.

Muhammad, Abulkadir, 1990, Hukum Perikatan, PT. Citra Aditya, Bandung. 2000, Hukum Acara Perdata Indonesia, PT. Citra Aditya Bakti, Bandung

Hadikusuma, H. Hilman, 2005, Bahasa Hukum Indonesia, PT.Alumni, Bandung.

Hamidi, Jazim 2005, Hermeneutika Hukum, UII Press, Yogyakarta.

Prakoso,Abintaro, 2016, Penemuan Hukum: System, Metode, Aliran dan Prosedur dalam Menemukan Hukum, LaksBang PRESSindo, Yogyakarta.

Salim, H.S., 2011, Pengantar Hukum Perdata Tertulis (BW), SInar Grafika, Jakarta.

Syaifuddin, Muhammad,2012, Hukum Kontrak Memahami Kontrak dalam Perspektif Filsafat, Teori, Dogmatik dan Praktik Hukum (Seri Pengayaan Hukum Perikatan), Mandar Maju, Bandung.

Universitas Udayana, 2015, Buku Pedoman Pendidikan Program Studi Magister Kenotariatan Universias Udayana, Denpasar.

\section{$\underline{\text { Peraturan Perundang-Undangan }}$}

Kitab Undang-Undang Hukum Perdata

Undang-Undang Nomor 1 Tahun 2011 tentang Perumahan dan Kawasan Pemukiman, Lembaran Negara Republik Indonesia Tahun 2011 Nomor 7 dan Tambahan Lembaran Nega Republik Indonesia Nomor 5188 
Peraturan Pemerintah Nomor 14 Tahun 2016 tentang Penyelenggaraan Perumahan dan Kawasan Pemukiman, Lembaran Negara Republik Indonesia Tahun 2016 Nomor 101 dan Tambahan Lembaran Negara Republik Indonesia.

\section{Jurnal}

Hasanah, U. (2013). Status kepemilikan tanah hasil konversi hak barat berdasarkan UU no. 5 tahun 1960 tentang peraturan dasar pokok-pokok Agraria dihubungkan dengan PP No. 24 tahun 1997 tentang pendaftaran tanah. Jurnal ilmu hukum, 3(01)., h. 1 